\title{
Genetic consequences of subtropical rainforest fragmentation on Macadamia tetraphylla (Proteaceae)
}

\author{
By C. S. SpAIN ${ }^{1), 2)}$ and A. J. LowE ${ }^{3), *)}$
}

(Received $4^{\text {th }}$ December 2010)

\begin{abstract}
Habitat fragmentation can bring about a variety of gene-flow alterations in plant populations, potentially threatening adaptive potential and local persistence. It is expected that following habitat fragmentation an increased level of inbreeding will be evident. In addition, a reduction in genetic diversity and increased genetic differentiation is expected following severe or long term population bottlenecks. We examined population genetic parameters for the subtropical rainforest tree Macadamia tetraphylla (Proteaceae) at six field sites throughout its recently fragmented range, using four microsatellite loci. Genetic diversity $\left(H_{\mathrm{E}}\right)$ of the juvenile cohort was significantly correlated with estimated population size. No significant difference was observed for genetic diversity between adult and juvenile cohorts, but juveniles, and not adults, exhibited significant population differentiation $(\theta=0.061 ; P<0.0001$ and $\theta=0.016$; $P=0.23$, respectively). A second, standardised measure of differentiation, $\theta^{\prime}$, yielded similarly large differences between the two cohorts, though higher estimates of differentiation overall (adults $-\theta^{\prime}=0.034$, juveniles $\left.\theta^{\prime}=0.116\right)$. The coefficient of population inbreeding $(f)$ was significant and positive in all juvenile, and four out of six adult, populations, and was significantly positively correlated with adult tree density, but not adult population size. Since fragmentation is relatively recent for this species, the population bottleneck must have been quite severe to have produced the observed patterns of population differentiation and genetic diversity. Fragmentation of forest across the study area over the last $100+$ years has led to the genetic isolation of M. tetraphylla populations resulting in increased population divergence and likely eventual loss of genetic variation in future generations.
\end{abstract}

Key words: Macadamia tetraphylla, subtropical rainforest, fragmentation, gene diversity, inbreeding coefficient, differentiation, microsatellites.

\section{Introduction}

Habitat fragmentation, the reduction of continuous tracts of vegetation to smaller, spatially distinct patches,

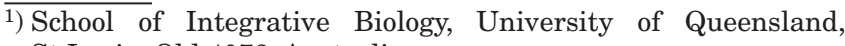
St Lucia, Qld 4072, Australia.

2) Current address: Biodiversity Assessment and Management, Suite 11, 2/20 Shore Street West Cleveland, QLD, 4163, Australia.

3) Australian Centre for Evolutionary Biology and Biodiversity, and School of Earth and Environmental Sciences, University of Adelaide, North Terrace, Adelaide SA 5005; State Herbarium of South Australia, Science Resource Centre, Department of Environment and Natural Resources, Hackney Road, Adelaide, SA 5005, Australia.

*) Author for correspondence: AndRew J. LowE. Phone: +61 434 607 705. E-mail: andrew.lowe@adelaide.edu.au.
}

is now a ubiquitous feature of much of the planet's forested areas (Young and Mitchell, 1994; LAURANCE and BierRegaARD, 1997; HobBs and YATES, 2003). Empirical studies examining the genetic impacts of habitat fragmentation have demonstrated that the process can bring about a variety of gene-flow alterations. Frequently, plant populations experience increased levels of inbreeding and random genetic drift following fragmentation (Young et al., 1996; DAYANANDAN et al., 1999; Collevatti et al., 2001; LIRA et al., 2003; CARDoso et al., 2005; Lowe et al., 2005). The magnitude of such gene flow alterations depends on the severity and duration of the reduction in population size (BARRET and KOHN, 1991). Where deforestation events lead to a reduction of gene flow between forest patches, the genetic bottlenecks experienced in fragmented populations can cause the independent loss of alleles from fragments, resulting in increased population differentiation (JUMP and PEÑUELAS, 2006).

To further understand the impact of fragmentation on an Australian subtropical rainforest species, we used microsatellites to estimate genetic parameters for the midstorey tree Macadamia tetraphylla (Proteaceae). Populations of $M$. tetraphylla were selected to represent the range of population sizes exhibited across its patchy distribution. The study took place in and around the Mt Warning Caldera, central eastern Australia (Figure 1). The vast majority of subtropical lowland rainforest vegetation in which $M$. tetraphylla grows was cleared between 145 and 105 years ago, with clearing beginning slightly earlier in more southerly areas (RITCHIE and PUGH, 1981).

Specifically, we aimed to determine: (1) whether larger or denser populations have higher levels of genetic diversity and lower levels of inbreeding, relative to smaller populations; and (2) whether the post-fragmentation (juvenile) cohort exhibits higher levels of inbreeding and differentiation among populations, compared with the pre-fragmentation (adult) cohort.

\section{Materials and Methods}

\section{Study Species}

Macadamia tetraphylla is a small to medium sized mid-storey rainforest tree that is endemic to central eastern Australia. Listed as vulnerable under both State and Federal legislation, concerns have been raised about its viability in the wild, over both the medium and long term (Gross, 1995). The species is patchily distributed within the regional landscape matrix, and is poorly represented in the reserve system. Populations are small (usually about 5-25 adults), with $<1000$ individuals 


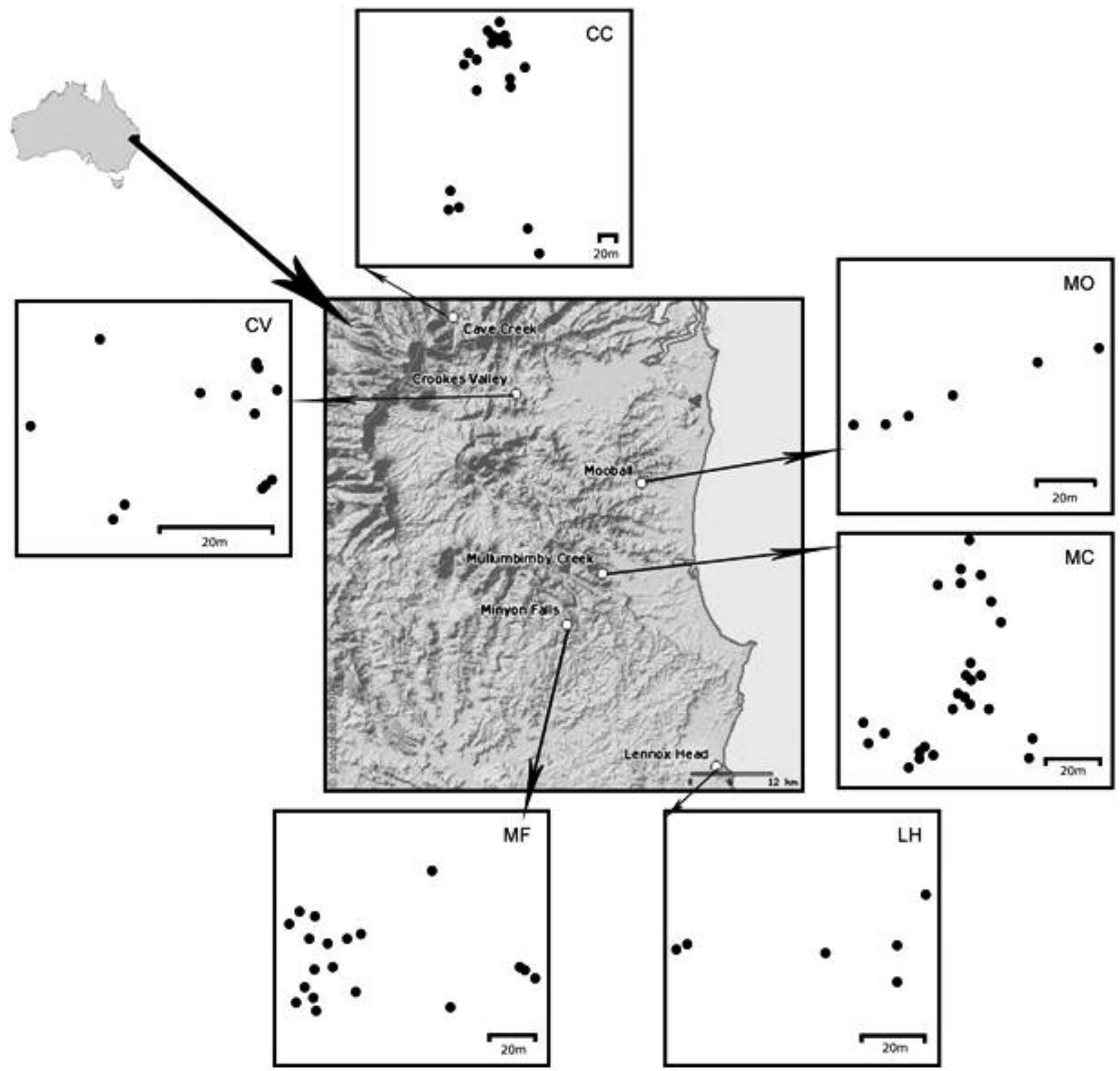

Figure 1. - Field sites used in this study, showing the distribution of all adult trees present within each site. Each dot represents a tree. Site abbreviations are shown in the corner of each box: CV-Crookes Valley; CC-Cave Creek; MO-Mooball; Mullumbimby Creek; LH-Lennox Head; MF-Minyon Falls.

estimated to be within conservation areas (PISANU, 2001). Its preservation is considered important, both in terms of biodiversity maintenance, and also because of the species' significance to the macadamia nut industry. The species is hermaphroditic, and flowers are borne on long racemes. The European honeybee, Apis mellifera, and native stingless bees, Trigona spp., are important pollinators in Australian macadamia orchards (HEARD, 1993, 1994; HEARD and EXLEY, 1994). In the wild, both of these pollinators have been observed on M. tetraphylla, with $A$. mellifera the more common of the two. However, overall pollinator activity appears to be low (PISANU, 2001; pers. obs.), with potential pollen limitation (PISANU, 2001). M. tetraphylla is estimated to have a lifespan of over 100 years, of which up to six years constitutes the juvenile period (QUEENSLAND CRA/RFA Steering Committee, 1997).
The level of fragmentation experienced by $M$. tetraphylla in natural populations is relevant to many other species in the region, especially endemics with limited population size or distribution, and so it can be considered a suitable case study species to examine the impact of fragmentation on the genetic dynamics of threatened plant populations in the region.

\section{Study sites and spatial mapping}

Six study sites were selected (Figure 1; Table 1), encompassing a range of adult population sizes. This range of population sizes is regarded as representative of the variety of situations in which $M$. tetraphylla can be found in the regional landscape matrix. All six of these study sites are bona fide wild populations, not the result of plantings by early settlers. 
Table 1. - Site characteristics and stratification for six populations of M. tetraphylla, central eastern, Australia.

\begin{tabular}{lcccccc}
\hline & \multicolumn{1}{l}{ Population } & & & & \\
\cline { 2 - 7 } Site characteristics & Mullumbimby Creek & Cave Creek & Minyon Falls & Crookes Valley & Lennox Head & Mooball \\
\hline Total adults within fragment & 37 & 22 & 20 & 15 & 6 & 6 \\
Est. total adults within $1 \mathrm{~km}$ radius & 71 & 47 & 26 & 32 & 19 & 11 \\
Mean distance between adults (m) & 5.86 & 11.54 & 9.44 & 5.77 & 10.81 & 14.78 \\
\hline
\end{tabular}

\section{Sample collection, DNA extraction and microsatellite survey}

For each population, genomic DNA from every adult (6-37) and 15-20 randomly selected juveniles was extracted using the QIAGEN DNeasy ${ }^{\mathrm{TM}}$ Plant Mini Kit. The standard protocol was followed, and success of DNA extractions and quantity of yield was determined by visualisation on $1.8 \%$ agarose gels (stained with ethidium bromide), using a 1000 BP ladder (HyperLadder I, Bioline). Based on screening and optimisation experiments, four polymorphic loci (Minus2, Minus7, MinuS14 and MinuS74) were selected from Schmidt et al. (2006) for genotyping the six populations. Samples were plated out onto 96 well trays and diluted 1:10. Ten percent of individuals were repeated in order to estimate the frequency of genotyping errors. Polymerase chain reaction (PCR) amplification was carried out in $20 \mu \mathrm{L}$ reaction volumes containing final concentrations of $\sim 20 \mathrm{ng}$ genomic DNA, 1xPCR Buffer, $2 \mathrm{mM} \mathrm{MgCl}, 0.2 \mathrm{mM}$ dNTPs, $0.094 \mu \mathrm{M}$ dye-labelled M13 forward, $0.006 \mu \mathrm{M}$ of M13 tagged forward primer, $0.1 \mu \mathrm{M}$ of reverse primer and 0.22 units Taq. The annealing temperatures $\left(T_{\mathrm{a}}\right)$ were $50^{\circ} \mathrm{C}$ for Minus2, Minus 7 and Min $\mu S 74$, and $53^{\circ} \mathrm{C}$ for Min $\mu$ S14. PCR amplification cycles are described in SCHMIDT et al. (2006). PCR products were visualised on $3 \%$ agarose, using a $500 \mathrm{BP}$ ladder (HyperLadder ${ }^{\mathrm{TM}} \mathrm{V}$, Bioline). Genotypes were determined using a Beckman Coulter ${ }^{\mathrm{TM}} \mathrm{CEQ}^{\mathrm{TM}} 8000$ System, and sized in comparison to SizeStandard-400. Scoring and binning of alleles was carried out using the $\mathrm{CEQ}^{\mathrm{TM}} 8000$ fragment analysis software package, with additional binnings being carried out manually. Repeat genotyping provided a genotyping error estimate of $1.69 \%$. We used the program MICROCHECKER (VAN OOSTERHOUT et al., 2004) to detect scoring errors resulting from the presence of null alleles as such artefacts are a well-known issue for microsatellites (Pompanon et al., 2005). Estimates of null allele frequency indicated that no loci showed evidence for null alleles.

\section{Data analysis}

Two pre-analysis tests of locus independence and suitability were carried out using Genepop 3.3 software (RAYMOND and Rousset, 1995): (1) a test for departure from Hardy-Weinberg ( $\mathrm{H}-\mathrm{W})$ expectations, with significance determined by a Bonferroni multiple testing procedure; (2) a test for significant linkage disequilibrium between locus pairs using Fisher's exact test. The following genetic diversity parameters were calculated: expected heterozygosity $\left(H_{\mathrm{E}}\right)$ (gene diversity) per locus using FSTAT 2.9.3 (GOUDET, 1995), and overall, using GENETIX 4.01 (BELKHIR et al., 1998); and number of alle- les $\left(A_{\mathrm{O}}\right)$ and effective number of alleles $\left(A_{\mathrm{E}}\right)$ using POPGENE (YEH et al., 1997).

Inbreeding coefficient $(f)$ and an index of differentiation $(\theta)$ were calculated following the formula of WEIR and Cockerham (1984), using FSTAT 2.9.3 (GOUdET, $1995)$. The significance of obtained global $F_{\mathrm{ST}}(\approx \theta)$ values were tested by performing 50,000 randomisations of genotypes among samples. $P$-values were generated by a simulation of 50,000 random permutations of genotypes among populations. Tests did not assume $\mathrm{H}-\mathrm{W}$ within populations. The influence of each locus on generating global $F_{\mathrm{ST}}$ estimates was examined by successive jackknifing across loci using GENETIX 4.01 (BELKHIR et al., 1998). We also calculated $\theta^{\prime}$, a standardised measure of $\theta$. This was done by transforming our genotype data in the utility RECODEDATA (MEIRMANs, 2006) such that each population only contained private alleles. By maximizing the different covariance components, we obtained values for $\theta_{(\max )}$. Following the method of HEDRICK (2005), the standardised measure was calculated by dividing the original $\theta$ value by the maximum value. We included estimation of $\theta^{\prime}$ in this study because traditional methods for estimating genetic population differentiation are dependent on the level of allelic diversity, whereas $\theta^{\prime}$ is standardised for all levels of genetic variation (HEDrick, 2005; Miermans, 2006; Miermans and HEDRICK, 2011). Tests for significance were not applicable to $\theta^{\prime}$ because the calculation of $\theta_{(\max )}$ relies on a modified dataset, rather than original genotype data (MIERMANS, 2006). Regression analyses were carried out using the 'analysis toolpak' extension in Excel ${ }^{\circledR}$ (Microsoft Corporation). All further analyses were conducted in $\mathrm{R}$ 2.13.1 (R Development CoRe Team, 2011).

\section{Results \\ Genetic diversity}

Locus characteristics. Across the 178 genotyped individuals, 54 alleles were identified. The highly polymorphic MinuS7 had 36 alleles, with the other three loci each exhibiting six alleles. The populations in the study showed no significant departures from $\mathrm{H}-\mathrm{W}$ expectations $(P=<0.0025$, following Bonferroni multiple-testing correction), apart from the adult cohort at Cave Creek $(n=15)$ for Minus74. Due to a lack of evidence of any similar departure from $\mathrm{H}-\mathrm{W}$ for any other populationcohort combination at this locus, it was retained for further analysis. No significant linkage disequilibrium was detected between the loci $(P=0.585-0.847)$, suggesting that they are independent. Accordingly, each locus was treated separately for analysis. 
Table 2. - Gene diversity $\left(H_{\mathrm{E}}\right)$, number of alleles $\left(A_{\mathrm{O}}\right)$ and effective number of alleles $\left(A_{\mathrm{E}}\right)$ for four microsatellite loci in six $M$. tetraphylla populations and overall, and averaged over loci. Software used: $H_{\mathrm{E}}$ for each locus-FSTAT 2.9.3 (GouDET, 1995); overall $H_{\mathrm{E}}$-GENETIX 4.01 (BELKHIR et al., 1998); $A_{\mathrm{O}}, A_{\mathrm{E}}$ - POPGENE (YEH et al., 1997). AC = adult cohort, JC=juvenile cohort.

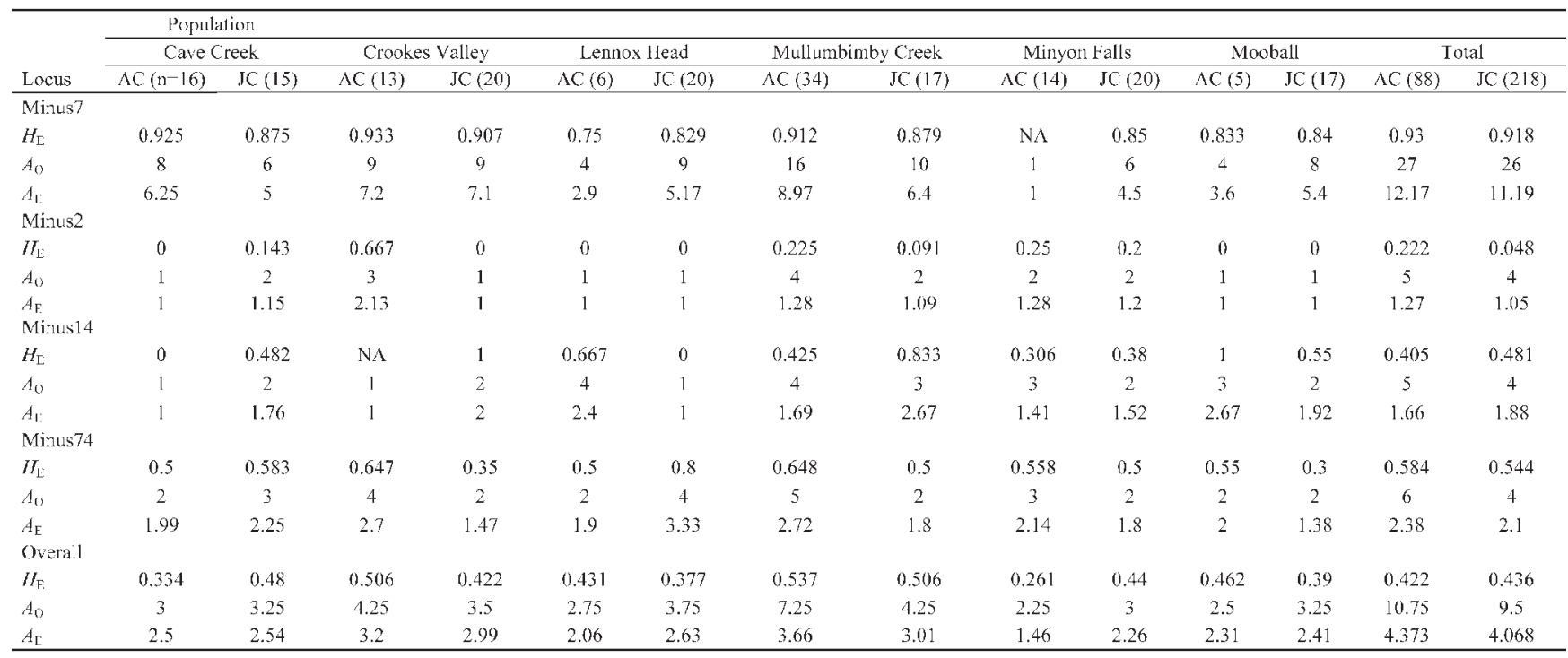

Number of alleles (A). The observed number of alleles $\left(A_{\mathrm{O}}\right)$ across loci ranged between $1-16$ in the adult cohort and 1-10 in the juvenile cohort (Table 2). Effective number of alleles $\left(A_{\mathrm{E}}\right)$ across loci ranged between 1-8.97 in the adult cohort and 1-7.5 in the juvenile cohort (Table 2 ), but did not differ significantly between adult and juvenile cohorts $(P=0.47)$.

\section{Genetic differentiation}

Levels of genetic differentiation among populations differed between adult and juvenile cohorts. There was no evidence of genetic structuring among the adult populations $(\theta=0.016, P=0.23$; Table 3$)$, but a higher and significant value was recorded for the juvenile cohort $(\theta=0.061, P>0.0001)$. Estimates of $\theta^{\prime}$ were higher than $\theta$ for both cohorts, but the measure exhibited a similar magnitude of difference between the two cohorts as $\theta$ (adults $-\theta^{\prime}=0.034$, juveniles $-\theta^{\prime}=0.116$ ).

\section{Inbreeding}

A positive and significant inbreeding coefficient $(f)$ was recorded both for adults $(0.132, P=0.002)$ and juve-

Table 3. - Differentiation $(\theta)$ and standardised differentiation $\left(\theta^{\prime}\right)$ values for the adult and juvenile cohorts of six populations of $M$. tetraphylla, at each locus individually and overall. Jackknife $\theta$ shows overall values for $\theta$ without each locus as well as mean and standard deviation values from jackknife procedure. Significant values denoted $*(P>0.0001) . A C=$ adult cohort, $\mathrm{JC}=$ juvenile cohort.

\begin{tabular}{lcccccc}
\hline & \multicolumn{3}{c}{$\theta$} & \multicolumn{2}{c}{ Jackknife $\theta$} & \multicolumn{2}{c}{$\theta^{\prime}$} \\
\cline { 2 - 7 } Locus & AC & JC & AC & IC & AC & IC \\
\hline Minus7 & 0.058 & $0.072^{*}$ & -0.016 & 0.051 & 0.509 & 0.526 \\
Minus2 & -0.002 & $0.022^{*}$ & 0.019 & 0.062 & -0.003 & 0.023 \\
Minus14 & -0.043 & 0.05 & 0.03 & 0.064 & -0.074 & 0.093 \\
Minus74 & -0.004 & 0.054 & 0.024 & 0.063 & 0.010 & 0.112 \\
All & 0.016 & $0.061^{*}$ & - & - & 0.034 & 0.116 \\
Mean & - & - & 0.024 & 0.063 & - & - \\
S. D. & - & - & 0.031 & 0.009 & - & - \\
\hline
\end{tabular}

niles $(0.209, P=0.0005)$, indicating that $M$. tetraphylla generally exhibits an excess of homozygotes. The juvenile cohort exhibited significant positive inbreeding coefficients at all sites (Figure 3), but only four of the six adult cohorts did. Juveniles showed higher levels of inbreeding in five out of the six populations (the Mooball population had considerable inbreeding coefficients for adult and juvenile cohorts of 0.11 and 0.09 respectively). But large sampling errors reveal these differences to be non-significant, and there was no relationship between adult population size and the level of inbreeding. A regression of juvenile inbreeding coefficient against the estimated total number of adults within a one kilometre radius at each site also showed no compelling correlation $\left(R^{2}=0.22, P=0.34\right)$. A significant negative correlation was observed between the level of inbreeding in the juvenile cohort and density of adult trees $(P=0.001)$, as

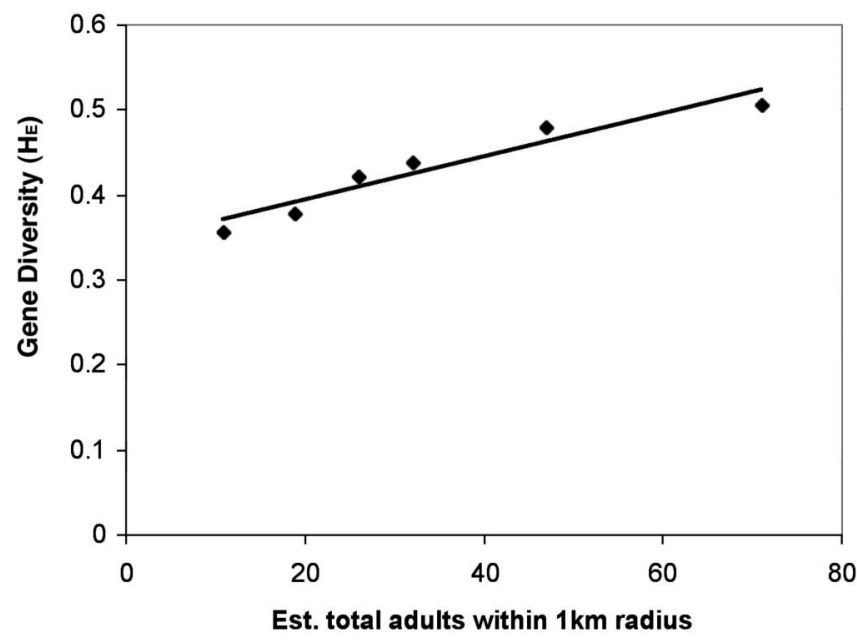

Figure 2. - Relationship between $H_{\mathrm{E}}$ in the juveniles cohort and the total number of adult trees estimated to be within a one kilometre radius following population census. 


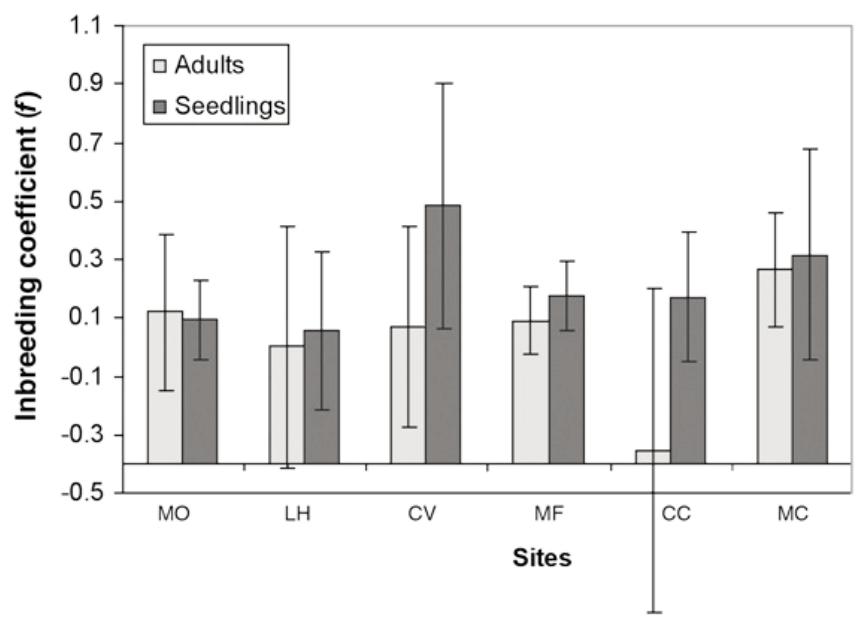

Figure 3. - Inbreeding coefficient $(f)$ across all loci. Sites are arranged from smallest to largest population sizes. Bars show standard errors.

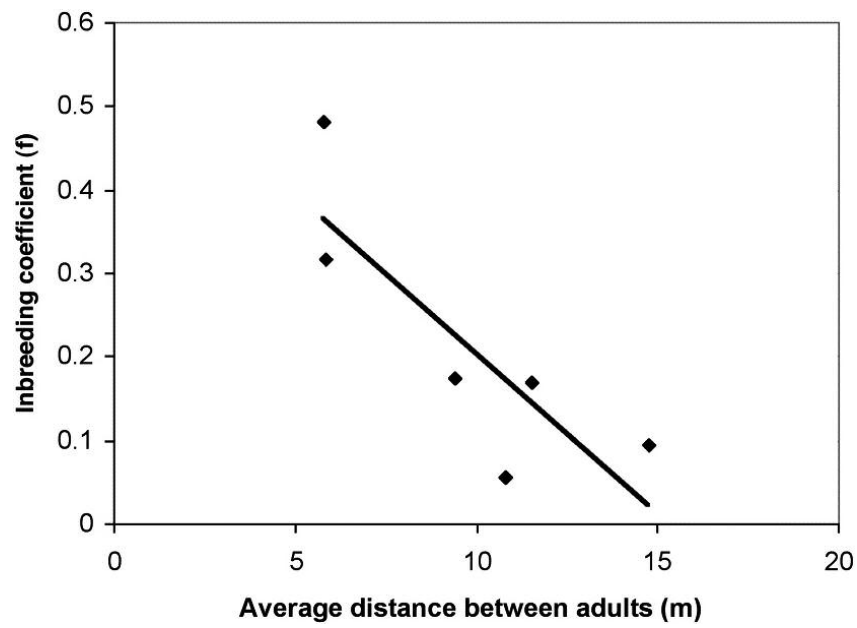

Figure 4. - Relationship between inbreeding coefficient $(f)$ for the juvenile cohort (averaged over all loci) and the mean nearest neighbour distance.

measured by mean nearest neighbour distance (Figure 4). Juveniles in populations with more clumped adult trees tended to have higher inbreeding scores than did sites where adults were more sparsely spaced.

\section{Discussion}

\section{Genetic diversity and differentiation}

Gene diversity estimates were not observed to be significantly different between adult and juvenile cohorts within a site or between sites. Modelling studies indicate that this parameter decreases only slowly following population size reduction (LOWE et al., 2005). Unlike the inbreeding coefficient, which reflects a redistribution of allelic variation in the form of reduced heterozygosity, relative to its $\mathrm{H}-\mathrm{W}$ expectation, an observable change in gene diversity may only become apparent after several generations (NEI et al., 1975; VARVIO et al., 1986; LOWE et al., 2005). In addition juveniles in this study are likely to be primarily the progeny of pre-fragmentation or early fragmentation parents, given the lifespan of the species, which will further buffer expected diversity loss. A regression of $H_{\mathrm{E}}$ against the estimated number of adults within a one kilometre radius did show a significant positive correlation $(P=0.002)$ (Figure 2$)$. Therefore a reduction in population size associated with fragmentation would be expected to reduce diversity over time.

Quantifying the extent of population differentiation in patchily distributed plant species can highlight the importance of gene flow in enabling populations to evolve together (STARR and CARTHEW, 1998). Among M. tetraphylla populations, significant differentiation was observed among the juvenile cohort $(\theta=0.061)$, but not among the adult cohort $(\theta=0.016)$. While $\theta^{\prime}$ showed a similar pattern between the two cohorts (adults $\theta^{\prime}=0.034$, juveniles $-\theta^{\prime}=0.116$, estimated levels of differentiation were higher for both, as expected for this type of measure (HEDRICK, 2005; JosT, 2008). The index reduces the downward bias known to be present in traditional estimators, and potentially provides a more accurate estimate of differentiation levels of $M$. tetraphylla populations. However as standardised measures such as $\theta^{\prime}$ cannot be easily interpreted in the context of basic demographic factors (WHITLOCK, 2011), and as the theoretical framework for this group of statistics is still being developed in the context of the broader evolutionary theory, it is prudent to report both traditional and standardised measures (LENG and ZHANG, 2011), as has been done here.

The lack of structure within the adult cohort suggests that, prior to habitat fragmentation, there was relatively unrestricted gene flow within a regionally continuous population. However since fragmentation, the data suggest that $M$. tetraphylla pollen flow between fragments has significantly decreased. A number of studies underscore the utility of comparing life-stages of tree populations to reveal insights into the dynamics of post-fragmentation gene flow. In a study of the tropical hardwood Carapa guianensis (DAYANANDAN et al., 1999), saplings within logged plots had higher differentiation than adults $\left(R_{\mathrm{ST}}=0.060\right.$ and 0.017 , respectively). The authors took this as evidence of restriction of gene flow as a result of landscape alterations. In a comparison of populations of the tropical canopy tree Symphonia globulifera in continuous compared to fragmented forest (ALDRICH et al., 1998), significant differentiation in both younger and older juveniles was found among sites. Also, saplings - but not adults - in continuous forest were significantly differentiated from those in surrounding fragments. These differences were observed despite the surrounding fragments having only been separated from the continuous patch for $10-30$ years. Such a pattern has also been recorded for other tree species (FARWig, 2008; Ortego et al., 2010), as well as a cycad (OCtavio-Aguilar, 2009). Yet post-fragmentation cohorts do not always display higher levels of differentiation than their pre-fragmentation counterparts: a number of studies have found low levels of differentiation for both cohorts (LATOUCHE-HALlÉ, 2003; SCHWARCZ et al., 2010), sometimes still with significantly higher values for juveniles than adults (RIBEIRO et al., 2005; FigueroAEsquivel, 2010). Alternatively, both may display high 
differentiation, for example where populations are naturally fragmented (KETTLE et al., 2008). The implications of the current study are that the fragmentation of the region's forests over the last 100+ years has led not only to spatial but also genetic isolation of $M$. tetraphylla populations. If this is the case, then the future of remnant stands of this species may be one of increased population divergence, and eventual loss of genetic variation. This is the scenario observed within modelling studies over many generations of restricted population sizes (Lowe et al., 2005).

\section{Inbreeding and population dynamics}

Significant levels of population level inbreeding were found within both juvenile and adult cohorts of $M$. tetraphylla, most likely due to crossing between closely related trees. As the juvenile populations in low disturbance continuous tracts of rainforest (Minyon Falls and Cave Creek) showed similar levels of inbreeding to those at other sites, it is possible that habitat fragmentation has not augmented inbreeding significantly. Juveniles in the majority of populations did show higher levels of inbreeding compared to adults, although the differences were not great (Figure 3), and on this basis the role of fragmentation in augmenting inbreeding cannot be confirmed or ruled out based on the data available. For the closely related congener $M$. integrifolia it was found that seedling emergence in small fragments was significantly greater than in medium fragments and continuous habitat, although trends in mortality at different growth stages was not investigated (NEAL et al., 2010). If seedling emergence is also elevated for fragmented M. tetraphylla populations and they survive to adulthood, then inbreeding may be further elevated in these disturbed habitats.

Investigations that utilise comparisons of genetic patterns at different life-history stages for recently fragmented populations can yield valuable insights into the current processes. However it should be noted that variation in levels of population inbreeding at each life-history stage may depend on the intensity of selection (HUFFORD and HAMRICK, 2003), independent of habitat fragmentation. It has been reported for a number of tree species that inbreeding is higher in the seedling cohort even in continuous forest (e.g., AlLY and RITLAND, 2007), probably because in a given sample this cohort represents a smaller age range than adult trees and hence the progeny of far fewer mating events (Hall et al., 2004).

A reduction in population size caused by habitat fragmentation in preferentially outcrossing species like $M$. tetraphylla would be expected to promote biparental inbreeding and increase inbreeding depression (DUDASH and Fenster, 2000; Francisco-Ortega et al., 2000; MATHIASEN et al., 2007; but see HoNNAY and JACQUEMYN, 2007). For the early successional rainforest tree Elaeocarpus grandis, sampled across the same region as this study, RossetTo et al. (2004) found a non-significant increase in inbreeding levels as population size declined. No relationship was observed here, possibly because the species occurs in small populations naturally. The lack of a compelling correlation between inbreeding coefficient and estimated total number of adults is potentially a function of the number of sites we surveyed. Future studies incorporating more populations should not discount possible relationship between inbreeding level and population size.

For some tree species, density has been found to influence pollination patterns, with the ratio of outcrossing higher at a lower adult tree density (IsAGI et al., 2007). We found a significant correlation between inbreeding and tree density: the closer adult trees were to one another, the more inbred the juveniles within a population (Figure 4). This relationship suggests family spatial structure may be causing inbreeding in fragmented populations. If dense populations have a high degree of genetic structuring, which seems likely, then the progeny of these trees are more likely to be inbred. This has been found to be the case for other rainforest trees (TAKEUCHI, 2010) as well as in herbaceous species (KITAмото et al., 2007). There may also be an interaction with pollinator behaviour, which is apparently influenced by interflowering-tree density (BAWA, 1998). When flowering trees are clumped, pollinators tend to follow nearneighbour behaviour, whereas when trees are broadly spaced the insect is more likely to miss the next closest tree in a fragment and simply fly to the next fragment (STACY et al., 1996). Such processes may influence fruit set (JONES and COMITA, 2008) and ultimately affect tree population dynamics.

The implications of tree density and fruit set for levels of inbreeding in $M$. tetraphylla are clearer when viewed in the light of a previous study on the species. PISANU (2001) found that raceme production decreased as nearneighbour density increased, and that this same pattern was reflected in seed production, although weakly so. The combined results of the two studies suggest that high adult tree density may not only result in decreased overall fecundity, but that those seeds that are produced may grow into juveniles exhibiting elevated levels of homozygosity in comparison to less dense populations. Seed dispersal of $M$. tetraphylla is by small rodents and gravity fall, probably with some assistance from local stream flooding (Costello et al., 2009). Dispersal distances for scatter-hoarding murid rodents appear to be quite short, usually between 5-20 m (CORLETT, 2009; CHOU, 2011). It is likely that apart from flooding events opportunities for significant seed exchange between populations is limited. If this is the case then germinating seeds will primarily be close to their parents. Consequently, changes associated with fragmentation such as restriction of inter-fragment gene flow and increased population density (by way of elevated seedling germination and survivorship in disturbed habitats) may augment inbreeding. There exists the potential for such interactions to have significant consequences for population viability, and this should be a focus of future research.

\section{Acknowledgements}

We thank: Two anonymous reviewers who provided helpful comments on earlier versions of the manuscript, Dominique SigG for assistance in the lab and help with 
data analysis and advice; ADELE SCHMIDT for assistance in the lab and application of loci; SANDIE DEGNAN and Peter Prentis for advice as well as comments and suggestions to an earlier draft of the manuscript; CECILE BACLES for advice and assistance with data analysis; PHIL PISANU for help with field site selection and advice; ROBERT PRICE for help with mapping; LUI WEBER for help with site selection; LANA HEYDON for help in the field; Germaine Greer for field site access; Rozina Suliman for logistical support; DAVID YATES for advice on fieldwork; JODI NEAL for advice on mapping; JINGCHAUN LI for assistance with genotyping; CRAIG HARDNER for his role in setting up the project. The Authors gratefully acknowledge the financial assistance of CSIRO Plant Industries.

\section{References}

Aldrich, P. R., J. L. Hamrick, P. Chavarriaga and G. Kochert (1998): Microsatellite analysis of demographic genetic structure in fragmented populations of the tropical tree Symphonia globulifera. Mol. Ecol., 7: 933-944.

BAWA, K. (1998): Conservation of genetic resources in the Dipterocarpaceae. In: A review of Dipterocarps: Taxonomy, ecology and silviculture, pp. 45-55, edited by A. Appanah, and J. M. TuRnbull. Center for International Forestry Research, Bogor, Indonesia.

BACles, C. F. E., A. J. Lowe and R. A. Ennos (2004): Genetic effects of chronic habitat fragmentation on tree species: the case of Sorbus aucuparia in a deforested Scottish landscape. Mol. Ecol., 13: 573-584.

BARRET, S. C. H. and J. R. KoHN (1991): Genetic and evolutionary consequences of small population size in plants: Implications for conservation. In: Genetics and conservation of rare plants, pp. 3-30, edited by D. A. FAlK and K. E. Holsinger. Oxford University Press, NY.

Belkhir, K., P. Borsa, J. Goudet, L. Chikhi and F. BonHOMME (1998): GENETIX logiciel sous Windows ${ }^{\mathrm{TM}}$ pour la génétique des populations. Laboratoire Génome et Populations, CNRS-UPR 9060, Montpellier, France.

Cardoso, S. R. S., J. Provan, C. C. D. Lira, L. D. R. Pereira, P. C. G. Ferreira and M. A. Cardoso (2005): High levels of genetic structuring as a result of population fragmentation in the tropical tree species Caesalpinia echinata Lam. Biodivers. and Conserv., 14: 1047-1057.

Chou, F. S., W-C. Lin, Y-H Chen and J-B. Tsai (2011): Seed fate of Castanopsis indica (Fagaceae) in a subtropical evergreen broadleaved forest. Bot. Stud., 52: 321-326.

Collevatti, R. G., D. Grattapaglia and J. D. Hay (2001): High resolution microsatellite based analysis of the mating system allows the detection of significant biparental inbreeding in Caryocar brasiliense, an endangered tropical tree species. Heredity, 86: 60-67.

CoRleTt, R. T. (2009): Seed dispersal distances and plant migration potential in tropical East Asia. Biotropica, 41: 592-598.

Costello, G., M. Gregory and P. Donatiu (2009): Southern Macadamia Species Recovery Plan 2008-2112. Report to Department of the Environment and Heritage, Canberra.

Dayanandan, S., J. Dole, K. Bawa and R. Kesseli (1999): Population structure delineated with microsatellite markers in fragmented populations of a tropical tree,
Carapa guianensis (Meliaceae). Mol. Ecol., 8: 1585-1592.

Dick, C. W. (2001): Genetic rescue of remnant tropical trees by an alien pollinator. Proc. R. Soc. Lond., B, Biol. Sci., 268: 2391-2396.

Dick, C. W., G. Etchelecu and F. Austerlitz (2003): Pollen dispersal of tropical trees (Dinizia excelsa: Fabaceae) by native insects and African honeybees in pristine and fragmented Amazonian rainforest. Mol. Ecol., 12: 753-764.

DudAsh, M. and C. B. Fenster (2000): Inbreeding and outbreeding depression in fragmented populations. In: Genetics, Demography and Viability of Fragmented Populations, pp. 35-53, edited by A. G. YounG, and G. M. ClaRKE. Cambridge University Press, Cambridge, UK.

Farwig, N., C. Braun and K. Böhning-Gaese (2007): Human disturbance reduces genetic diversity of an endangered tropical tree, Prunus africana (Rosaceae). Cons. Gen., 9: 317-326.

Francisco-Ortega, J., A. SANTos-Guerra, S. C. Kim and D. J. CRAWFord (2000): Plant genetic diversity in the Canary Islands: A conservation perspective. Am. J. Bot., 87: 909-919.

Figueroa-Esquivel, E. M., F. Puebla-Olivares, L. E. Eguiarte and J. NúÑEZ-FARFÁN (2010): Genetic structure of a bird-dispersed tropical tree (Dendropanax arboreus) in a fragmented landscape in Mexico. Rev. Mex. Biodivers., 81: 789-800.

GOUDET, J. (1995): FSTAT (Version 1.2): A computer program to calculate F-statistics. J. Hered., 86: 485-486.

Gross, C. L. (1995): Macadamia tetraphylla. In: Report on Rare and Threatened Plants of North-eastern NSW, pp. 180-185, edited by F. C. Quinn, J. B. Williams, C. L Gross, and J. J. BruHL. Dept. Botany/Dept. Ecosystem Management, UNE, Armidale.

Hall, P., M. R. Chase and K. S. BAwA (1994): Low genetic variation but high population differentiation in a common tropical forest tree species. Cons. Biol., 8: 471-482

HEDRICK, P. W. (2005): A standardized genetic differentiation measure. Evolution, 59: 1633.

HonNAY, O. and H. JACQUEMYN (2007): Susceptibility of common and rare plant species to the genetic consequences of habitat fragmentation. Conserv. Biol. 21: 823-831.

HEARD, T. A. (1993): Pollinator requirements and flowering patterns of Macadamia integrifolia. Aust. J. Bot., 41, 491-497.

HEARD, T. A. (1994): Behaviour and pollinator efficiency of stingless bees and honey-bees on Macadamia flowers. J. Apic. Res., 33: 191-198.

HEARD, T. A. and E. M. ExLey (1994): Diversity, abundance, and distribution of insect visitors to Macadamia flowers. Environ. Entomol., 23: 91-100.

HobBs, R. J. and C. J. YATES (2003): Impacts of ecosystem fragmentation on plant populations: generalising the idiosyncratic. Aust. J. Bot., 51: 471-488.

Isagi, Y., R. TAteno, Y. Matsuki, A. Hirao, S. Watanabe and M. SHIBATA (2007): Genetic and reproductive consequences of forest fragmentation for populations of Magnolia obovata. Ecol. Res., 22: 382-389.

Jones, F. A. and L. S. ComitA (2008): Neighbourhood density and genetic relatedness interact to determine fruit set and abortion rates in a continuous tropical tree population. Proc. R. Soc. B., 275: 1652-2759. 
Jost, L. (2008): $\mathrm{G}_{\mathrm{ST}}$ and its relatives do not measure differentiation. Mol. Ecol., 17: 4015-4026.

JumP, A. S. and J. PeÑUelas (2006): Genetic effects of chronic habitat fragmentation in a wind-pollinated tree. Proc. Natl. Acad. Sci. U.S.A., 103: 8096-8100.

KANG, M., J. WANG and H. HuANG (2008): Demographic bottlenecks and low gene flow in remnant populations of the critically endangered Berchemiella wilsonii var. pubipetiolata (Rhamnaceae) inferred from microsatellite markers. Conserv. Genet., 9: 191-199.

Kettle, C. J., P. M. Hollingsworth, T. Jaffré, B. Moran and R. A. EnNos (2007): Identifying the early genetic consequences of habitat degradation in a highly threatened tropical conifer, Araucaria nemorosa Laubenfels. Mol. Ecol., 16: 3581-91.

Kitamoto, N., S. Ueno, Y. Tsumura, I. Washitani and I. OHSAWA (2007): Effect of population density of compatible neighbours on inbreeding level within a Primula sieboldii population. Ecol. Res., 23: 307-315.

latouche-Hallé, C., A. Ramboer, E. Bandou, H. Caron and A. KREMER (2003): Nuclear and chloroplast genetic structure indicate fine-scale spatial dynamics in a neotropical tree population. Heredity, 91: 181-90.

Laurance, W. F. and R. O. BierRegaARD (1997): Preface: A crisis in the making. In: Tropical Forest Remnants: Ecology, Management, and Conservation of Fragmented Communities, pp. xi-xv, edited by R. O. BIERREGAARD and W. F. LAURANCE. University of Chicago Press, Chicago.

Leimu, R. and P. Mutikainen (2005): Population history, mating system, and fitness variation in a perennial herb with a fragmented distribution. Conserv. Biol., 19: 349-356.

Lira, C. F., S. R. S. Cardoso, P. C. G. Ferreira, M. A. CARDOSO and J. PROVAN (2003): Long-term population isolation in the endangered tropical tree species Caesalpinia echinata Lam. revealed by chloroplast microsatellites. Mol. Ecol., 12: 3219-3225.

Lowe, A. J., D. Boshier, M. WARD, C. F. E. BACles and C. NAVARRO (2005): Genetic resource impacts of habitat loss and degradation; reconciling empirical evidence and predicted theory for neotropical trees. Heredity, 95: 255-273.

Mathiasen, P., A. E. Rovere and A. C. Premoli (2007): Genetic structure and early effects of inbreeding in fragmented temperate forests of a self-incompatible tree, Embothrium coccineum. Conserv. Biol., 21: 232-240.

Meirmans, P. G. and P. W. Hedrick (2011): Assessing population structure: $F_{\mathrm{ST}}$ and related measures. Mol. Ecol. Res. 11: 5-18.

NASON, J. D. and J. L. HAMRICK (1997): Reproductive and genetic consequences of forest fragmentation: Two case studies of neotropical canopy trees. J. Hered., 88: 264-276.

NeAL, J. M., C. M. HARDNer and C. L. Gross (2010): Population demography and fecundity do not decline with habitat fragmentation in the rainforest tree Macadamia integrifolia (Proteaceae). Biol. Cons., 143 2591-2600.

NeI, M., T. Maruyama and R. Chakraborty (1975): The bottleneck effect and genetic variability of populations. Evolution, 29: 1-10.

Octavio-Aguilar, P., J. GonzÁlez-Astorga and A. P. VOVIDES (2009): Genetic diversity through life history of Dioon edule Lindley (Zamiaceae, Cycadales). Plant Biol., 11: 525-36.
OOstermeiJer, J. G. B., M. W. VAN EiJCK, N. C. VAN LEEUWEN and J. C. M. DEN NIJS (1995): Analysis of the relationship between allozyme heterozygosity and fitness in the rare Gentiana pneumonanthe L. J. Evol. Biol., 8: 739-757.

Ortego, J., R. Bonal and A. MuÑoz (2010): Genetic consequences of habitat fragmentation in long-lived tree species: the case of the Mediterranean Holm Oak (Quercus ilex, L.). J. Hered., 101: 717-26.

Pompanon, F., A. Bonin, E. Bellemain and P. TABerlet (2005): Genotyping errors: causes, consequences and solutions. Nat. Rev. Gen., 6: 847-59.

PisAnU, P. C. (2001): Survivorship of the threatened subtropical rainforest tree Macadamia tetraphylla L. Johnson (Proteaceae) in small habitat fragments. [dissertation] University of New England, Armidale.

Queensland CRA/RFA Steering Committee (1997): Forest taxa at risk, threats, conservation needs and recovery planning in south-east Queensland. Queensland Government \& Commonwealth of Australia.

R Development Core Team (2011): R: A language and environment for statistical computing. $R$ Foundation for Statistical Computing, Vienna, Austria.

RAYMOND, M. and F. ROUSSET (1995): GENEPOP (Version1.2) - population-genetics software for exact tests and ecumenicism. J. Hered., 86: 248-249.

Ribeiro, R. A., A. C. Simões Ramos, J. P. De Lemos Filho and M. B. Lovato (2005): Genetic variation in remnant populations of Dalbergia nigra (Papilionoideae), an endangered tree from the Brazilian Atlantic Forest. Ann. Bot, 95: 1171-7.

RITCHIE, R. and D. PUGH (1981): A guide to rainforests of far north east New South Wales. The Authors, Lismore, N.S.W.

Rossetto, M., R. Jones and J. Hunter (2004): Genetic effects of rainforest fragmentation in an early successional tree (Elaeocarpus grandis). Heredity, 93: 610-618

SchmidT, A. L., L. ScotT and A. J. Lowe (2006): Isolation and characterisation of microsatellite loci from Macadamia integrifolia. Mol. Ecol. Notes, 6: 1060-1063.

Stacy, E. A., J. L. HAMrick, J. D. NAson, S. P. HubBell, R. B. Foster and R. Condit (1996): Pollen dispersal in low-density populations of three neotropical tree species. Am. Nat., 148: 275-298.

StARR, G. J. and S. M. CARTHEW (1998): Genetic differentiation in isolated populations of Hakea carinata (Proteaceae). Aust. J. Bot., 46: 671-682.

Schwarcz, K. D., C. L. Pataca, A. G. Abreu, J. M. Bariani, C. M. T. MACRINI and V. N. Solferini (2010): Genetic diversity in Atlantic Forest trees: fragmentation effects on Astronium graveolens (Anacardiaceae) and Metrodorea nigra (Rutaceae), species with distinct seed dispersal strategies. Bot. J. Linn. Soc., 164: 326-336.

Takeuchi, Y., H. Samejima, M. Nakagawa, B. Diway and T. NAKASHIZUKA (2010): Neighborhood aggregation effect and its effective scale on reproductive success in Shorea laxa (Dipterocarpaceae). J. Plant Res., 123: 249-259.

Varvio, S. L., R. Chakraborty and M. Nei (1986): Genetic variation in subdivided populations and conservation genetics. Heredity, 57: 189-198.

Van Oosterhout, C., W. F. Hutchinson, D. P. M. Wills and P. SHIPLEY (2004): Micro-Checker: software for identifying and correcting genotyping errors in microsatellite data. Mol. Ecol. Notes, 4: 535-538. 
WhitLock, M. C. (2011): $\mathrm{G}_{\mathrm{ST}}$ and D do not replace $\mathrm{F}_{\mathrm{ST}}$. Mol. Ecol., 20: 1083-91.

WeIR, B. S. and C. C. Cockerham (1984): Estimating F-statistics for the analysis of population-structure. Evolution, 38: 1358-1370.

Young, A., T. BoYle and T. BRown (1996): The population genetic consequences of habitat fragmentation for plants. Trends Ecol. Evol., 11: 413-418.
Young, A. and N. Mitchell (1994): Microclimate and vegetation edge effects in a fragmented podocarp-broadleaf forest in New Zealand. Biol. Conserv., 67: 63-72.

Yeh, F. C., R-C. Yang, T. B. J. Boyle, Z-H. Ye and J. X. MaO (1997): POPGENE, the user-friendly shareware for population genetic analysis. Molecular Biology and Biotechnology Centre, University of Alberta, Canada.

\title{
Strong Genetic Control of High Wood Specific Gravity in Young Progenies of Pinus brutia: Potential of Early Selection for Industrial Plantations
}

\author{
By K. YILDIRIM ${ }^{1)}$, H. ÖZTÜRK ${ }^{2)}$, S. SiKLAR ${ }^{2)}$, O. D. BALKIZ ${ }^{2)}$ and Z. KAYA ${ }^{1), *}$
}

(Received $17^{\text {th }}$ December 2010)

\begin{abstract}
To increase quality and amount of wood production in Turkish red pine (Pinus brutia Ten.), genetic control of wood specific gravity (WSG), tracheid length and growth traits was investigated in Ceyhan1A progeny trial by evaluating 168 families originated from six clonal Turkish red pine seed orchards. Wood samples were taken by destructive sampling during the rouging of this trial at the age of seven. Differences among the 168 families for mean WSG was large (ranged from 0.35 to 0.62 ), as indicated by high individual $(0.42 \pm 0.07)$ and family mean $(0.55 \pm 0.03)$ heritabilities. Family differences and high heritabilities were also observed for all growth traits and tracheid length. Genetic correlations between WSG and growth traits were insignificant (near zero), while low and insignificant negative phenotypic correlations among the same traits were also observed. Predicted genetic gain for single trait selection at age of seven was low for WSG $(0.37 \%)$, but substantial for stem volume $(8.4 \%)$ in phenotypic seed orchards. However, the first generation clonal seed orchards consisting of the best 30 clones yielded higher genetic gains $(5.2 \%$ for WSG and $35 \%$ for stem volume). These preliminary results suggest that selection for wood characteristics and growth traits in Turkish pine could be practiced at early ages for short rotation (about 30 years) in industrial plantations.
\end{abstract}

Key words: Pinus brutia, Wood Specific Gravity, Progeny Test, Heritabilities, Genetic and Phenotypic Correlations, Genetic Gain.

1) Department of Biological Sciences, Middle East Technical University, 06531 Ankara, Turkey.

2) Forest Trees and Seeds Breeding Research Directorates, Ministry of Environment and Forestry, Ankara, Turkey.

*) Corresponding author: ZEKI KAYA. Phone: (+90) 3122105177. E-Mail: kayaz@metu.edu.tr.

\section{Introduction}

Turkish red pine (Pinus brutia Ten.) is naturally distributed in the Mediterranean and Aegean regions of Turkey (ANONYMOUS, 2006). It grows on an extremely wide range of ecological, climatic, and geographical gradients, from sea level up to an elevation of 1500 meters (FIscher et al., 2008). Total forest cover of the species is estimated to be approximately 4 million hectares, which constitutes about $50 \%$ of the coniferous and $20 \%$ of the total forest area in the country (FISCHER et al., 2008). The species is also one of the most valuable commercial trees providing both timber resources and amenities. Due to its high wood density and long, suitable wood fibers for pulp and paper production, adaptability to arid conditions, fast growth and early flowering, Turkish red pine is considered as an excellent choice for industrial plantations (GEZER and AsLAN, 1980; GEZER, 1986; UstA, 1991; ICGEN et al., 2006). Evaluation of the optimal rotation age for industrial plantations of Turkish red pine indicates that with intensive silvicultural treatments and on good sites, the optimum volume for harvesting could be achieved as early as age 27 in the species (UsTA, 1991).

In Turkey, tree breeding programs were firstly initiated by delineating seed procurement and deployment zones. Although selection of seed stands and plus trees and establishment of first generation clonal seed orchards were completed for many tree species in $1960 \mathrm{~s}$, a systematic-long term breeding plan was not available until preparation of "National Tree Breeding and Seed Production Programme (NTBP) for Turkey" (KoskI and ANTOLA, 1993). With NTBP, five main tree species, including Turkish red pine, were given the highest priority and defined as target species for intensive tree breeding studies. 